\title{
Introduction. Travel Writing and Cultural Terrae Incognitae: Ongoing Ethical and Theoretical Dilemmas
}

\author{
Corinne Fowler, \\ University of Stirling, Scotland \\ Ludmilla Kostova, \\ University of Veliko Turnovo, Bulgaria
}

As we stretched out for the night in the usual fashion of sardines, the ancient proprietor swept a space for me on the floor. He leaned towards me and asked in a whisper what my bakhsheesh [tip] might be for him. I took out my pen and said it was there; one day I would write about this place and he would be famous. 'What's the good of that?' he scoffed, and sank into the darkness. Jason Eliot, An Unexpected Light. Travels in Afghanistan (1999)

s a hybrid discourse cutting across generic and disciplinary bound-
of intercultural relations, travel writing has found itself at the centre of a
widening field of intellectual inquiry. This special issue focuses on the
ethical parameters of travel in a range of texts produced in a variety of
historical and national contexts. While the topic is not strikingly novel,
the editors and contributors to this issue nevertheless believe that their
critical interventions engage fruitfully both with earlier interpretations
and current theoretical paradigms. The six essays that comprise this issue
concentrate on specific ethical dilemmas, neither attempting fusion into a
coherent body of theory nor constructing all-purpose systems of
classification, but preferring instead to tackle critical practices and
preconceptions from a variety of competing perspectives. As early as 1985
Mary Louise Pratt defined travel writing as 'one of the most polyphonous
of genres', thereby alerting scholars to its resistance to the 'disciplined' 


\section{Introduction}

mediation of cultural differences (Pratt 1985: 141) and hinting at the futility of generalizing methods of analysis. Taking into account the distinctive features of the object of inquiry itself, the site-specific contributions to this issue are in tune with the anti-universalist thrust of most present-day critical practice.

This special issue therefore concentrates on a number of specific ethical dilemmas. These pertain to the traveller's ethical and narrative stance, to her or his gender, to the quest for originality (and its attendant anxieties), to multiple relationships to power, strategies of cross-cultural representation, and (often troubled and troubling) relationships to dominant discourses about the places being visited. Correspondingly, the essays engage with the numerous theoretical predicaments faced by scholars in the field, both in their theorization of travel writing and their negotiation of particular minefields, moral and political as well as intellectual. Perhaps inevitably, the predicaments faced by the traveller (an appellation that automatically generates concerns about the exclusive nature of such a category) spread like a contagion to the travel writing scholar who, commonly embarking on travels of her or his own, is intensely conscious of travel's long association with violence, whether it concerns that 'peculiarly destructive brand of nomadism called colonialism' (Laurent Dubois in Behar and Gordon 1995: 314) or, to extend the category of traveller, migrants fleeing the wars emblazoned across so many television screens beneath the logo of CNN.

How, then, are scholars to mine the rich resources of ethnographic, feminist and postcolonial theories without imposing them arbitrarily on a bewildering array of travel scenes and settings? Over the last five or six years, there has been increasing and justifiable concern over the use of insights culled indiscriminately from the paradigm of postcolonial studies. (Steve Clark's important edited collection Travel Writing and Empire (1999) warns against the danger of extracting postcolonial theories from the contexts that engendered them). It has, however, also been remarked that establishing analogies between colonial situations and aspects of the relationship, say, between Eastern and Western Europe 'is an approach that, if used with reason (and if historicized) has validity and can be fruitful' (Fleming 2000: 1221). Wherever the contributors to the present issue have engaged with postcolonial theories, great care has been 
taken to avoid the pitfalls described by Clark and others by combining close attention to the historical conditions under which the travel writing was produced with a specialist focus upon particular dilemmas associated with the places discussed. Waldemar Zacharasiewicz has for the most part remained loyal to his early conditioning within the context of European 'imagology'; as a result he engages with postcolonial theories only sporadically, yet his essay nevertheless suggests that fusing the two fields (with great care) can be productive and mutually enriching. Corinne Fowler and Jopi Nyman maintain a more familiar focus on the encounter between the global West and the global East and their approach is entirely justified: Nyman explores the unfamiliar terrain of travel writing on the internet while Fowler scrutinizes journalists' post-September 11th travel writing about Afghanistan. Importantly, Shaul Bassi and Barbara Del Mercato, Maria Gouloubeva, and Ludmilla Kostova set out to test the limits of postcolonial theories and their modifications at the hands of Larry Wolff and other scholars by exploring relationships between travellers and 'travellees' in geographical regions that did not experience any form of conventional 'Western' imperialism. The undertaking is risky, yet they acquit themselves by maintaining a historicised perspective throughout, continually demonstrating their awareness of the differences between their respective objects of analysis and more familiar sites of postcolonial inquiry.

The authors' engagement with the cross-section of gender and travel writing studies should also be noted. Increasingly, travel writing can no longer be understood as synonymous with men's travel writing. Furthermore, there is growing recognition that women's travel writing is best studied alongside that of men. In their recently published anthology of women's travel writing, Shirley Foster and Sara Mills appear to recommend that theirs be the last anthology of its kind. 'Ideally', they argue, 'we would like to see anthologies of travel writing and critical essays on travel writing which do not make any essentialist assumptions, which refer equally to men's and women's work' (2002: 5). Foregrounding texts outside the established corpus, many of the articles raise the profile of some important writing by women (Catherine Maria Sedgewick and Mary E. Church Terrell on Germany; Elisa von Rieke on Poland; Georgina Muir Mackenzie, Adeline Paulina Irby, Emily Anne Strangford and Fanny 


\section{Introduction}

Janet Blunt on the Balkans; Christina Lamb on Afghanistan), taking account of gender-related determinations and negotiations while ensuring that women's travel writing is never considered in isolation from its male counterpart. Indeed, one of the most troubling legacies with which critics of travel writing have had to deal relates to reductive distinctions along gender lines ('good' women versus 'bad' male travellers or, alternatively, 'bad' women travellers who adopt symbolic masculine identities to further their own emancipation). Notions of women's travel writing as ipso facto subversive of received discourses are avoided and easy parallels between travel and (proto)feminism firmly resisted. While maintaining a clear focus on the significance of gender to dilemmas of cross-cultural representation is clearly valuable, there is broad recognition among the contributors that mapping the multiple trajectories of power requires a focus on both gender and genre, attending to, for example, the critical relationship between travel writing and ethnography, or the relationship between gender and the choice of narrative form, whether it be a letter, a diary or a memoir.

Throughout the issue there is a systematic refusal to consider the correspondence of place to the real or actual. As a result the articles reap the benefits of their site-specific foci, attending to ways in which a single place, whether it be Afghanistan, Bulgaria, Germany, Greece, Latvia, Turkey, Venice or Vietnam, is no mere piece of earth but rather a site crammed with competing representations. As Charles Warner suggested about Egypt, if the lines written about any single country 'were laid over the country, every part of it would be covered by as many as 365 miles to the inch' (Derek and Gregory 1999: 114). As critics of travel writing have discovered, it is this intricate web of representations that is of vital critical importance rather than any notion of 'actual' place.

Finally, we welcome the way in which scholars, suspicious of received representations, have begun to read for, and against, the limits of the discourse. This special issue therefore addresses itself to one of travel writing's most profound ethical dilemmas: is that which ethnographers have exposed about their own writing doubly true of travellers? Are areas identified as cultural, rather than geographical, terrae incognitae forever destined to remain just that? 


\section{References}

Behar, R. and Gordon, D. (eds) (1995) Women Writing Culture, Berkeley: University of California Press.

Bohls, E.A. (1995) Women Travel Writers and the Language of Aesthetics, Cambridge: Cambridge University Press.

Clark, S. (1999) Travel Writing and Empire. Postcolonial Theory in Transit, London: Zed Books.

Duncan, J. and Gregory, D. (1999) Writes of Passage. Reading Travel Writing, London: Routledge.

Eliot, J. (1999) An Unexpected Light. Travels in Afghanistan, London: Picador.

Fleming, K.E. (2000) 'Orientalism, the Balkans, and Balkan Historiography', American Historical Review, 104, 4: 1218-33.

Foster, S. and Mills, S. (eds) (2002) An Anthology of Women's Travel Writing, Manchester: Manchester University Press.

Leask, N. (2002) Curiosity and the Aesthetics of Travel Writing, Oxford: Oxford University Press.

Pratt, M.L. (1985) 'Scratches on the Face of the Country; or What Mr. Barrow saw in the Land of the Bushmen', Critical Inquiry 12, 1: 119-42. 